\title{
Phycicola gilvus gen. nov., sp. nov., an actinobacterium isolated from living seaweed
}

Correspondence
Soon Dong Lee
sdlee@cheju.ac.kr

The family Microbacteriaceae Park et al. 1993 emend. Rainey, Ward-Rainey and Stackebrandt 1997 (Park et al., 1993; Stackebrandt et al., 1997) as originally described comprised seven actinobacterial genera, namely Microbacterium (the type genus), Agrococcus, Agromyces, Aureobacterium, Clavibacter, Curtobacterium and Rathibacter, and was characterized chemotaxonomically by the combination of B-type peptidoglycan and unsaturated menaquinones. Since then, 17 genera, including the recently described genera Microcella (Tiago et al., 2005), Yonghaparkia (Yoon et al., 2006) and Labedella (Lee, 2007), have been included in the family on the basis of data from polyphasic studies. Among

Abbreviation: DAB, 2,4-diaminobutyric acid.

The GenBank/EMBL/DDBJ accession number for the $16 \mathrm{~S}$ rRNA gene sequence of strain SSWW- $21^{\top}$ is AM286414. members of the family, Salinibacterium amurskyense (Han et al., 2003) and Labedella gwakjiensis (Lee, 2007) were recently isolated from marine environments, i.e. seawater and dried seaweed, respectively.

Strain SSWW- $21^{\mathrm{T}}$ was isolated from a living seaweed sample collected around Samyang Beach in Jeju, Republic of Korea. Seaweed samples were scraped from rock surfaces of a beach with a spatula and placed directly into sterilized 50-ml Falcon tubes. For bacterial isolation, a seaweed sample $(1 \mathrm{~g})$ was placed into a test tube containing $9 \mathrm{ml}$ sterile seawater and mixed in a tube rotator for $30 \mathrm{~min}$. After serial dilution of the sample with sterile seawater, the diluents were transferred onto SC-SW agar plates containing sterilized natural seawater (Lee, 2006). A colony on the plates, incubated at $30{ }^{\circ} \mathrm{C}$ for 14 days, was subcultured on YE-SW medium $(0.4 \%$ yeast extract, $1.0 \%$ malt extract, 
$0.4 \%$ glucose and $1.8 \%$ agar in a mixture of $60 \%$ seawater and $40 \%$ distilled water) and the pure culture was maintained in $20 \%(\mathrm{v} / \mathrm{v})$ glycerol supplemented with $60 \%$ sterilized seawater at -20 and $-80{ }^{\circ} \mathrm{C}$.

Cell morphology and motility were investigated by using an Olympus light microscope equipped with phasecontrast optics (magnification $\times 400$ ) and a model JEM1200EXII transmission electron microscope (JEOL). Cells of strain SSWW- $21^{\mathrm{T}}$ were cultivated in trypticase soy broth (TSB; Difco) at $30{ }^{\circ} \mathrm{C}$ for $6,15,24,48$ and $72 \mathrm{~h}$. Colony pigmentation and morphology were observed by using 7day cultures grown at $30{ }^{\circ} \mathrm{C}$ on trypticase soy agar (TSA; Difco). Growth was tested at different temperatures $(4,10$, $25,30,37$ and $\left.42{ }^{\circ} \mathrm{C}\right)$ and $\mathrm{pH}(4.1-10.1) . \mathrm{NaCl}$ tolerance for growth was investigated on ISP 2 medium (Shirling \& Gottlieb, 1966) supplemented with 1-9\% (w/v) $\mathrm{NaCl}$. Tests for degradation and hydrolysis of several compounds, Gram staining and catalase and oxidase activities were carried out as described by Lee (2006). Urease activity was tested by using Bacto urea broth (Difco). Acid production from carbohydrates and alcohols was determined by using Bacto OF basal medium (Difco) as described by Lee (2007). Tests with API 20E and API ZYM strips (bioMérieux) were performed according to the manufacturer's instructions.

Cells of strain SSWW- $21^{\mathrm{T}}$ were rod-shaped or coccoid depending on culture age (Fig. 1). Rod-shaped cells were observed in young cultures. Older cultures predominantly revealed coccoid cells that were arranged singly or rarely in pairs. V cell arrangements and branching were not found. Both rod and coccoid forms were Gram-positive. Rods were motile by means of flagella, but coccoid cells were non-motile. Budding-like morphology was also observed (Fig. 1b). Such budding-like morphology has not previously been reported for recognized members of the Microbacteriaceae. The results of other cultural, physiological and biochemical tests are given in the genus and species descriptions below.

Extraction of genomic DNA, PCR amplification and direct sequencing of the 16S rRNA gene and phylogenetic analyses were performed as described by Lee (2006). The 16S rRNA gene sequence (1406 nt) of strain SSWW-21 ${ }^{\mathrm{T}}$ was aligned with the corresponding sequences retrieved from public databases by using CLUSTAL_X software (Thompson et al., 1997). A final tree was developed by using the neighbour-joining method (Saitou \& Nei, 1987) and the model of Jukes \& Cantor (1969), on the basis of 1353 unambiguously aligned positions of the sequences of all test strains. Strain SSWW- $21^{\mathrm{T}}$ formed a distinct phylogenetic branch within the radiation of the family Microbacteriaceae and was loosely associated with members of the genus Agrococcus (Fig. 2). This relationship was supported by a moderate bootstrap value ( $58 \%$ ), but was also found in both the maximum-parsimony and maximum-likelihood trees. Strain SSWW- $21^{\mathrm{T}}$ showed highest $16 \mathrm{~S}$ rRNA gene sequence similarities to the type strains of Okibacterium fritillariae (96.8\%), Leifsonia poae (96.8\%) and Agreia bicolorata (96.6\%). Strain SSWW-21 $1^{\mathrm{T}}$ showed levels of $16 \mathrm{~S}$ rRNA gene sequence similarity of 93.1-96.3\% to representatives of other genera within the family Microbacteriaceae.

Purified cell walls were prepared by the method of Schleifer \& Kandler (1972). The molar ratios of amino acids were
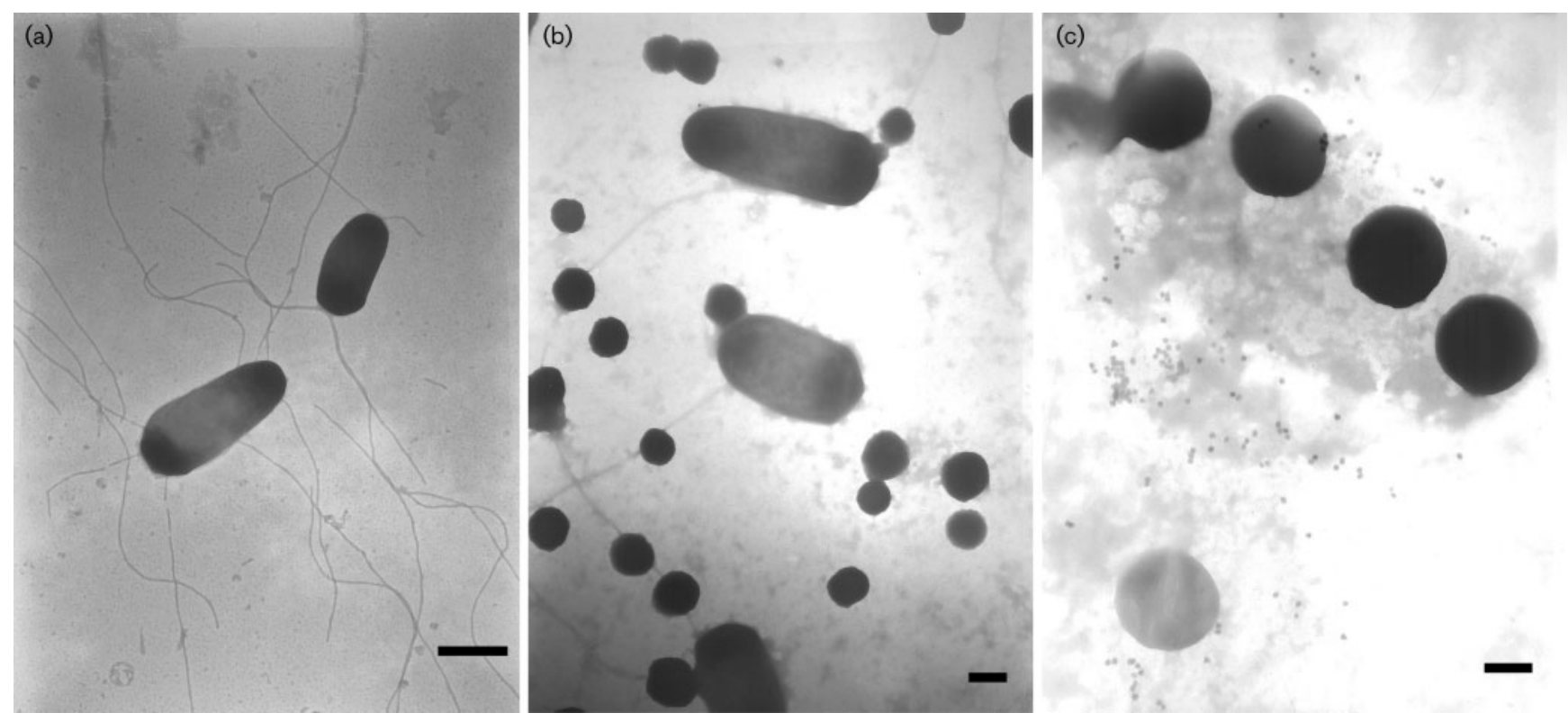

Fig. 1. Transmission electron micrographs of cells of strain SSWW- $21^{\top}$ cultivated in TSB at $30{ }^{\circ} \mathrm{C}$ for 24 (a), 48 (b) and 72 (c) h. Bars, 500 (a), 200 (b) and 100 (c) nm. 


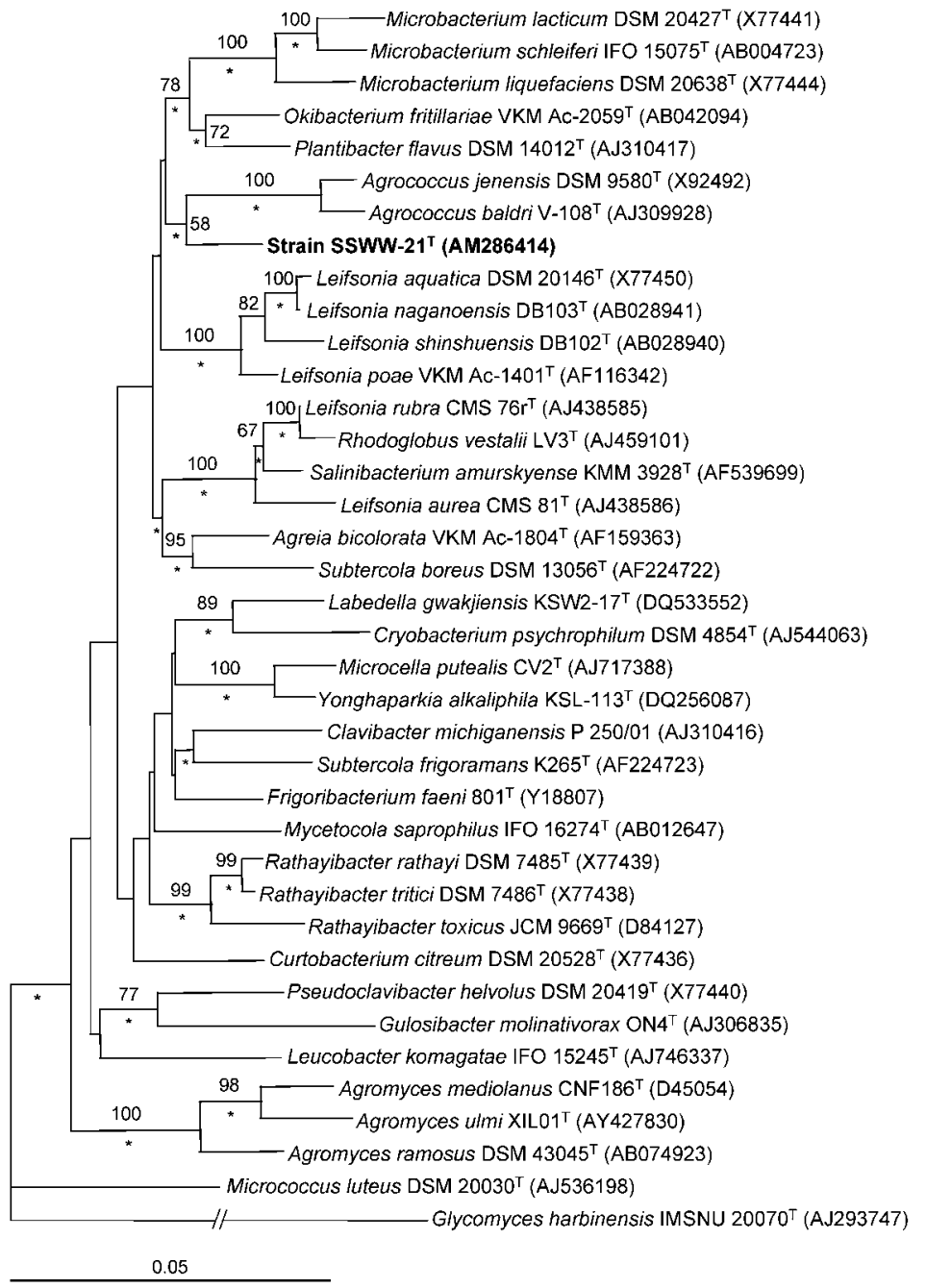

Fig. 2. Neighbour-joining tree showing the phylogenetic position of SSWW- $21^{\top}$ within the family Microbacteriaceae. Asterisks indicate branches that were also found in both the maximum-likelihood (Felsenstein, 1981) and maximum-parsimony (Fitch, 1971) trees. Numbers at nodes indicate bootstrap support values (Felsenstein, 1985), based on 1000 replications (only values $>40 \%$ are indicated). Bar, 0.05 substitutions per nucleotide position. determined by GC and GC-MS of N-heptafluorobutyryl amino acid isobutyl esters, as described by MacKenzie (1987). The amino acids and peptides in cell-wall hydrolysates were analysed by two-dimensional TLC on cellulose plates, as described by Schleifer \& Kandler (1972). The molar ratio of alanine/glycine/2,4-diaminobutyric acid (DAB)/glutamic acid was estimated to be $0.6: 1.2: 1.5: 1.0$. The diagnostic diamino acid in the cell-wall peptidoglycan was DAB. Homoserine was not detected in the peptidoglycan hydrolysates. The partial hydrolysates contained the peptide Gly-Glu typical of B-type peptidoglycans. From these data, the peptidoglycan of strain $S S W W-21^{\mathrm{T}}$ was inferred to be of B2 $\gamma$ type (or B7; see http://www.dsmz.de/ species/murein.htm). Analyses of polar lipids (Minnikin et al., 1977), isoprenoid quinones (Kroppenstedt, 1985), mycolic acids (Minnikin et al., 1980) and the acyl type of murein (Uchida \& Aida, 1984) were performed as described previously. Cells were cultivated in TSB for 3 days at $30{ }^{\circ} \mathrm{C}$, washed (after harvesting by centrifugation) with distilled water and freeze-dried. The polar lipid profile of strain SSWW- $21^{\mathrm{T}}$ contained phosphatidylcholine, phosphatidylglycerol, phosphatidylinositol and diphosphatidylglycerol (Fig. 3). The identification of phosphatidylcholine was finally confirmed by TLC of a polar lipid extract supplemented with authentic phosphatidylcholine (Sigma). The presence of phosphatidylcholine is unusual in the family Microbacteriaceae and can serve as a key marker for distinguishing the novel isolate from members of genera within the family. The major menaquinone was MK-11 (71\%). Minor amounts of MK-10 (15\%), MK-12 $(9 \%)$ and MK-9 (5\%) were also detected. No mycolic acids were present. The $\mathrm{G}+\mathrm{C}$ content of the DNA was determined by HPLC according to the method of Mesbah et al. (1989). The DNA G $+C$ content of strain SSWW- $21^{\mathrm{T}}$ was $69.8 \mathrm{~mol} \%$.

Preparation and analysis of cellular fatty acid methyl esters were performed by GC according to the standard protocols of the Sherlock Microbial Identification System (version 6; MIDI), by using 3 -day cultures grown on TSA at $30{ }^{\circ} \mathrm{C}$. The predominant fatty acids were anteiso- $\mathrm{C}_{15: 0}(49.7 \%)$ and anteiso- $\mathrm{C}_{17: 0}(27.3 \%)$. The following fatty acids were 


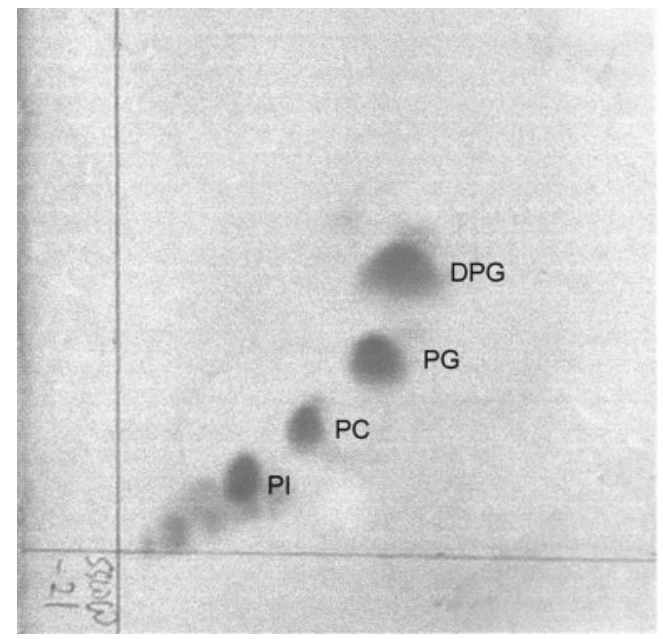

Fig. 3. Polar lipid profile of strain $S S W W-21^{\top}$. DPG, Diphosphatidylglycerol; PC, phosphatidylcholine; PG, phosphatidylglycerol; PI, phosphatidylinositol.

present as minor components: iso- $\mathrm{C}_{16: 0}(6.1 \%), \mathrm{C}_{16: 0}$ $(5.1 \%), \mathrm{C}_{18: 0}(5.0 \%)$, iso- $\mathrm{C}_{15: 0}(3.6 \%)$ and iso- $\mathrm{C}_{17: 0}$ $(2.6 \%)$. Other components $(<1 \%)$ were $\mathrm{C}_{9: 0}$ and iso$\mathrm{C}_{14: 0}$.

Differential phenotypic characteristics between strain SSWW $-21^{\mathrm{T}}$ and members of related genera in the family Microbacteriaceae are given in Table 1. The new isolate can also be distinguished from all other genera within the family Microbacteriaceae based on its polar lipid profile and budding-like cell division. On the basis of the phenotypic and molecular genetic data presented here, strain SSWW$21^{\mathrm{T}}$ is considered to represent a novel species of a new genus within the family Microbacteriaceae, for which the name Phycicola gilvus gen. nov., sp. nov. is proposed.

\section{Description of Phycicola gen. nov.}

Phycicola [Phy'ci.co.la. L. n. phycos -i (from Gr. n. phukos) seaweed; L. masc. suffix -cola inhabitant; N.L. masc. n. Phycicola inhabitant of seaweed].

Cells are aerobic, Gram-positive, catalase-positive, nonspore-forming, non-mycelium-forming. Cells are rodshaped or coccoid depending on culture age. Budding-like morphology may be observed. Cell-wall peptidoglycan is of the B-type (DAB as the diagnostic diamino acid). The acyl type of the muramic acid is acetyl. The predominant menaquinone is MK-11. The polar lipid profile contains phosphatidylcholine, phosphatidylglycerol, phosphatidylinositol and diphosphatidylglycerol. Mycolic acids are not present. The major cellular fatty acids are saturated branched-chain components (anteiso- $\mathrm{C}_{15: 0}$ and anteiso$\mathrm{C}_{17: 0}$ ). Phylogenetically, the genus belongs to the family Microbacteriaceae, suborder Micrococcineae. The type species is Phycicola gilvus.

\section{Description of Phycicola gilvus sp. nov.}

Phycicola gilvus (gil'vus. L. masc. adj. gilvus pale yellowcoloured).

Has the following characteristics in addition to those given for the genus above. Young cultures contain rod-shaped cells $(0.40-0.50 \times 0.80-1.20 \mu \mathrm{m})$, whereas older cultures contain coccoid cells $(0.18-0.33 \mu \mathrm{m}$ in diameter). Rods are motile by means of flagella, but coccoid cells are nonmotile. Colonies are circular, smooth, entire and reach 1$2 \mathrm{~mm}$ in diameter after 5 days incubation on TSA. Colony colour is variable depending on culture conditions;

Table 1. Differential phenotypic characteristics between strain SSWW- $21^{\top}$ and members of related genera in the family Microbacteriaceae

Taxa: 1, strain SSWW-21 ${ }^{\mathrm{T}}$; 2, Agreia (data from Evtushenko et al., 2001; Schumann et al., 2003); 3, Leifsonia (Evtushenko et al., 2000; Suzuki et al., 1999); 4, Okibacterium (Evtushenko et al., 2002). Orn, D-Ornithine; DPG, diphosphatidylglycerol; PG, phosphatidylglycerol; PC, phosphatidylcholine; PI, phosphatidylinositol; v, variable depending on species. Strain SSWW- $21^{\mathrm{T}}$ can be distinguished from all other genera of the family Microbacteriaceae based on its polar lipid profile and budding-like cell division.

\begin{tabular}{|lcccc|}
\hline Characteristic & $\mathbf{1}$ & $\mathbf{2}$ & $\mathbf{3}$ & $\mathbf{4}$ \\
\hline Cell morphology & Short rods to cocci & Irregular rods & Irregular rods or filaments & $\begin{array}{c}\text { Irregular rods or oval to } \\
\text { irregular cocci }\end{array}$ \\
Budding-like cell division & & - & - & - \\
Diphtheroid arrangement & - & + & + & + \\
Motility & + & V & V & LyB \\
Diamino acid(s) & DAB & DAB, Orn & Acetyl & Glycolyl \\
Acyl type of murein & Acetyl & Acetyl & 11,10 or 11,12 & 10,11 \\
Major menaquinone(s) & 11 & 10 or 10,11 & DPG, PG & DPG, PG \\
Phospholipids & DPG, PC, PG, PI & DPG, PG & $66-73$ & 67 \\
DNA G+C content (mol\%) & 69.8 & $65-67$ & & \\
\hline
\end{tabular}


colonies are white when cells are incubated in the dark, but yellow when incubated in the light. Oxidase-negative. The temperature range for growth is $4-30{ }^{\circ} \mathrm{C}$, with optimum growth at $25{ }^{\circ} \mathrm{C}$. No growth occurs at $\geqslant 37{ }^{\circ} \mathrm{C}$. The $\mathrm{pH}$ range for growth is $\mathrm{pH}$ 6.1-10.1, with optimum growth at $\mathrm{pH} 7.1-8.1$. Growth occurs in the presence of $2 \% \mathrm{NaCl}$ but not with $3 \% \mathrm{NaCl}$. Indole and $\mathrm{H}_{2} \mathrm{~S}$ are not produced. Nitrate is reduced to nitrite. Unable to utilize citrate. Voges-Proskauer test is weakly positive. Negative for arginine dihydrolase, lysine decarboxylase, ornithine decarboxylase and tryptophan deaminase. Hydrolyses aesculin but not casein, elastin, starch, gelatin or urea. Decomposition of hypoxanthine, DL-tyrosine and xanthine does not occur. Acid is produced from L-arabinose, cellobiose, dextran, D-galactose, D-glucose, glycerol, maltose, L-rhamnose, D-ribose, salicin and sucrose. Acid production from D-arabinose and D-xylose is weak. Acid is not produced from the following carbon and energy sources: adonitol, 2,3-butanediol, dulcitol, meso-erythritol, D-fructose, myo-inositol, inulin, D-lactose, D-mannitol, Dmannose, melezitose, melibiose, methyl $\alpha$-D-glucoside, methyl $\alpha$-D-mannoside, 1,2-propanediol, raffinose, Dsorbitol, L-sorbose, trehalose or D-xylitol. In tests with the API ZYM system, positive for alkaline phosphatase, leucine arylamidase, naphthol-AS-BI phosphohydrolase, acid phosphatase and $\alpha$-glucosidase. Weakly positive for esterase lipase (C8), trypsin, $\beta$-glucosidase and $N$-acetyl- $\beta$ glucosaminidase. The following enzyme activities give negative responses: esterase (C4), lipase (C14), valine arylamidase, cystine arylamidase, $\alpha$-chymotrypsin, $\alpha$-galactosidase, $\beta$-galactosidase, $\alpha$-glucuronidase, $\alpha$-mannosidase and $\alpha$-fucosidase. The major fatty acids are anteiso- $\mathrm{C}_{15: 0}$ $(49.7 \%)$ and anteiso- $\mathrm{C}_{17: 0}(27.3 \%)$. The $\mathrm{G}+\mathrm{C}$ content of the DNA is $69.8 \mathrm{~mol} \%$.

The type strain, SSWW $-21^{\mathrm{T}}\left(=\mathrm{KCTC} 19185^{\mathrm{T}}=\mathrm{DSM}\right.$ $18319^{\mathrm{T}}$ ), was isolated from a living seaweed sample collected on the coast of Jeju, Republic of Korea.

\section{Acknowledgements}

This work was supported by the 21C Frontier Microbial Genomics and Application Center Program, Ministry of Science \& Technology, Republic of Korea, and a grant (no. BDM 0100211) to J. M. L from the Strategic National R\&D program through the Genetic Resources and Information Network Center funded by the Korean Ministry of Science and Technology.

\section{References}

Evtushenko, L. I., Dorofeeva, L. V., Subbotin, S. A., Cole, J. R. \& Tiedje, J. M. (2000). Leifsonia poae gen. nov., sp. nov., isolated from nematode galls on Poa annua, and reclassification of 'Corynebacterium aquaticum' Leifson 1962 as Leifsonia aquatica (ex Leifson 1962) gen. nov., nom. rev., comb. nov. and Clavibacter xyli Davis et al. 1984 with two subspecies as Leifsonia xyli (Davis et al. 1984) gen. nov., comb. nov. Int J Syst Evol Microbiol 50, 371-380.

Evtushenko, L. I., Dorofeeva, L. V., Dobrovolskaya, T. G., Streshinskaya, G. M., Subbotin, S. A. \& Tiedie, J. M. (2001). Agreia bicolorata gen. nov., sp. nov., to accommodate actinobacteria isolated from narrow reed grass infected by the nematode Heteroanguina graminophila. Int J Syst Evol Microbiol 51, 2073-2079.

Evtushenko, L. I., Dorofeeva, L. V., Krausova, V. I., Gavrish, E. Y., Yashina, S. G. \& Takeuchi, M. (2002). Okibacterium fritillariae gen. nov., sp. nov., a novel genus of the family Microbacteriaceae. Int J Syst Evol Microbiol 52, 987-993.

Felsenstein, J. (1981). Evolutionary trees from DNA sequences: a maximum likelihood approach. J Mol Evol 17, 368-376.

Felsenstein, J. (1985). Confidence limits on phylogenies: an approach using the bootstrap. Evolution 39, 783-791.

Fitch, W. M. (1971). Toward defining the course of evolution: minimum change for a specific tree topology. Syst Zool 20, 406-416.

Han, S. K., Nedashkovskaya, O. I., Mikhailov, V. V., Kim, S. B. \& Bae, K. S. (2003). Salinibacterium amurskyense gen. nov., sp. nov., a novel genus of the family Microbacteriaceae from the marine environment. Int J Syst Evol Microbiol 53, 2061-2066.

Jukes, T. H. \& Cantor, C. R. (1969). Evolution of protein molecules. In Mammalian Protein Metabolism, vol. 3, pp. 21-132. Edited by H. N. Munro. New York: Academic Press.

Kroppenstedt, R. M. (1985). Fatty acid and menaquinone analysis of actinomycetes and related organisms. In Chemical Methods in Bacterial Systematics, pp. 173-199. Edited by M. Goodfellow \& D. E. Minnikin. London: Academic Press.

Lee, S. D. (2006). Blastococcus jejuensis sp. nov., an actinomycete from beach sediment, and emended description of the genus Blastococcus Ahrens and Moll 1970. Int J Syst Evol Microbiol 56, 2391-2396.

Lee, S. D. (2007). Labedella gwakjiensis gen. nov., sp. nov., a novel actinomycete of the family Microbacteriaceae. Int J Syst Evol Microbiol 57, 2498-2502.

MacKenzie, S. L. (1987). Gas chromatographic analysis of amino acids as the $N$-heptafluorobutyryl isobutyl esters. J Assoc Off Anal Chem 70, 151-160.

Mesbah, M., Premachandran, U. \& Whitman, W. B. (1989). Precise measurement of the $\mathrm{G}+\mathrm{C}$ content of deoxyribonucleic acid by highperformance liquid chromatography. Int J Syst Bacteriol 39, 159-167.

Minnikin, D. E., Patel, P. V., Alshamaony, L. \& Goodfellow, M. (1977). Polar lipid composition in the classification of Nocardia and related bacteria. Int J Syst Bacteriol 27, 104-117.

Minnikin, D. E., Hutchinson, I. G., Caldicott, A. B. \& Goodfellow, M. (1980). Thin layer chromatography of methanolysates of mycolic acid-containing bacteria. J Chromatogr 188, 221-233.

Park, Y. H., Suzuki, K., Yim, D. G., Lee, K. C., Kim, E., Yoon, J., Kim, S., Kho, Y. H., Goodfellow, M. \& other authors (1993). Suprageneric classification of peptidoglycan group B actinomycetes by nucleotide sequencing of 5S ribosomal RNA. Antonie van Leeuwenhoek 94, 307-313.

Saitou, N. \& Nei, M. (1987). The neighbor-joining method: a new method for reconstructing phylogenetic trees. Mol Biol Evol 4, 406-425.

Schleifer, K. H. \& Kandler, O. (1972). Peptidoglycan types of bacterial cell walls and their taxonomic implications. Bacteriol Rev 36, 407-477.

Schumann, P., Behrendt, U., Ulrich, A. \& Suzuki, K. (2003). Reclassification of Subtercola pratensis (Behrendt et al. 2002) as Agreia pratensis comb. nov. Int J Syst Evol Microbiol 53, 2041-2044.

Shirling, E. B. \& Gottlieb, D. (1966). Methods for characterization of Streptomyces species. Int J Syst Bacteriol 16, 313-340.

Stackebrandt, E., Rainey, F. A. \& Ward-Rainey, N. L. (1997). Proposal for a new hierarchic classification system, Actinobacteria classis nov. Int J Syst Bacteriol 47, 479-491.

Suzuki, K., Suzuki, M., Sasaki, J., Park, Y.-H. \& Komagata, K. (1999). Leifsonia gen. nov., a genus for 2,4-diaminobutyric acid-containing 
actinomycetes to accommodate "Corynebacterium aquaticum" Leifson 1962 and Clavibacter xyli subsp. cynodontis Davis et al. 1984. J Gen Appl Microbiol 45, 253-262.

Thompson, J. D., Gibson, T. J., Plewniak, F., Jeanmougin, F. \& Higgins, D. G. (1997). The CLUSTAL_X windows interface: flexible strategies for multiple sequence alignment aided by quality analysis tools. Nucleic Acids Res 25, 4876-4882.

Tiago, I., Pires, C., Mendes, V., Morais, P. V., Costa, M. \& Verissimo, A. (2005). Microcella putealis gen. nov., sp. nov., a Gram-positive alkaliphilic bacterium isolated from a nonsaline alkaline groundwater. Syst Appl Microbiol 28, 479-487.

Uchida, K. \& Aida, K. (1984). An improved method for the glycolate test for simple identification of acyl type of bacterial cell walls. J Gen Appl Microbiol 30, 131-134.

Yoon, J.-H., Kang, S.-J., Schumann, P. \& Oh, T.-K. (2006). Yonghaparkia alkaliphila gen. nov., sp. nov., a novel member of the family Microbacteriaceae isolated from an alkaline soil. Int J Syst Evol Microbiol 56, 2415-2420. 